\title{
Isolation, Identification, and Antimicrobial Susceptibility Pattern of Shiga toxin-producing Escherichia Coli 0157:H7 from Food of Bovine Origin in Mekelle, Tigray, Ethiopia
}

\section{Million Weldeselassie}

Shire Agricultural Technical Vocational and Education Training College, Tigray

Getachew Gugsa ( $\nabla$ gugsag@yahoo.com )

Wollo University, School of Veterinary Medicine, Amhara

Yisehak Tsegaye

Mekelle University, College of Veterinary Sciences, Tigray

Nesibu Awol

Wollo University, School of Veterinary Medicine, Amhara

Ashwani Kumar

Addis Ababa University, College of Agriculture and Veterinary Medicine, Addis Ababa

Meselu Ahmed

Wollo University, School of Veterinary Medicine, Amhara

Nigus Abebe

Mekelle University, College of Veterinary Sciences, Tigray

\section{Habtamu Taddele}

Mekelle University, College of Veterinary Sciences, Tigray

Abrha Bsrat

Mekelle University, College of Veterinary Sciences, Tigray

\section{Research Article}

Keywords: Antimicrobial, Bacteriological, Bovine, E. coli 0157:H7, Food, Mekelle, Molecular

Posted Date: July 14th, 2021

DOl: https://doi.org/10.21203/rs.3.rs-692904/v1

License: (c) (1) This work is licensed under a Creative Commons Attribution 4.0 International License. Read Full License 


\section{Abstract}

Background: Escherichia coli 0157:H7 is an emerging and major zoonotic foodborne pathogen with an increasing concern for the emergence and spread of antimicrobial-resistant strains which may results in sporadic cases to serious outbreaks in the whole world. Cattle have been identified as a major reservoir of the pathogen. This study aimed to isolate and characterize Shiga toxin-producing E. coli 0157:H7 from raw milk, yogurt, and meat of bovine origin and determine their antimicrobial susceptibility pattern.

Methods: A cross-sectional study was conducted from December 2014-June 2015 and a total of 284 milk and meat were collected from different sources in Mekelle. The collected samples were analyzed for the presence of E. coli and Shiga toxin-producing E. coli 0157:H7 and determination of their antimicrobial susceptibility pattern following the standard bacteriological and molecular techniques and procedures, and antimicrobial sensitivity test.

Results: Out of the total 284 samples, $70(24.64 \%)$ were positive bacteriologically to E. coli and $14.29 \%$ were found to be Shiga toxin-producing E. coli 0157:H7. All (100\%) E. coli isolates carried the pal and $41.67 \%$ eae gene (EHEC). Of these EHEC isolates $40 \%$ and $60 \%$ were positive for stx 1 and stx 2 , respectively. E. coli isolates were showed the highest level of sensitivity for Gentamycin (91.7\%) but the highest level of resistance to Amoxicillin (95.8\%). Of the tested isolates, $18(75 \%)$ of E. coli showed multiple antimicrobial resistance.

Conclusions: The current study revealed the occurrence of Shiga toxin-producing E. coli 0157:H7 in foods of bovine origin in the study area. So, there is a chance of acquiring infection via the consumption of raw or undercooked food of bovine origin. Thus, awareness creation should be made on foodborne disease caused by Shiga toxin-producing E. coli 0157:H7 with due consideration on the safe handling and consumption of food of animal origin.

\section{Background}

In Ethiopia, both food shortage and lack of appropriate food safety assurance systems are problems that have become obstacles to the country's economic development and public health safety [1,2]. Animal products are generally regarded as high-risk commodities in respect of pathogen contents, natural toxins, and other possible contaminants and adulterants [3]. Foodborne microorganisms are major pathogens affecting food safety and cause human illness worldwide as a result of the consumption of foodstuff, mainly animal products contaminated with vegetative pathogens or their toxins. Most of these microbes have zoonotic importance resulting in a significant impact on both public health and economic sectors [4]. Moreover, the emergence of multidrug-resistant pathogens presents a global challenge for treating and preventing disease spread through zoonotic transmission [5].

Data regarding foodborne diseases are extremely scarce at a national level and a few studies conducted in different parts of the country showed the poor sanitary conditions of catering establishments and the 
presence of pathogenic organisms like Campylobacter, Salmonella, Staphylococcus aureus, Bacillus cereus, and Escherichia coli $[6,7,8,9,10]$.

E. coli found in humans can be categorized on basis of genetic and clinical criteria into three main groups: commensal, pathogenic (enteric or diarrheagenic), and extraintestinal pathogenic E. coli (ExPEC) [11]. The typical diarrheagenic strains include: enterotoxigenic (ETEC), enterohemorrhagic (EHEC), enteroinvasive (EIEC), enteropathogenic (EPEC) and enteroaggregative (EAEC) E. coli $[12,13]$. The E. coli that cause enteric disease have been divided into pathotypes, based on their virulence factors and mechanisms by which they cause disease $[11,14]$. One of these pathotypes, called Shiga toxin-producing E. coli (STEC), refers to those strains of $E$. coli that produce at least 1 member of a class of potent cytotoxins called Shiga toxin. The STEC are also called verotoxin-producing E. coli (VTEC). The names Shiga toxin (Stx), derived from similarity to a cytotoxin produced by Shigella dysenteriae serotype 1 [15], and verotoxin (VT), based on cytotoxicity for Vero cells [16] are used interchangeably. Those STEC that cause hemorrhagic colitis and hemolytic uremic syndrome are called enterohemorrhagic E. coli (EHEC) $[14,17]$. The Shiga toxin-producing E. coli 0157 is synonymous with E. coli $0157: \mathrm{H} 7[18,19]$. Pathogenicity of E. coli 0157: $\mathrm{H} 7$ is encoded by a variety of plasmid, bacteriophage, and chromosomal genes [20]. The key virulence factor for the subset of EHEC is the Shiga toxin (Stx) family which contains two subgroups: Stx 1 and Stx2-that share approximately 55\% amino acid homology [11]. The ability to produce Shiga toxin was acquired from a bacteriophage presumably directly or indirectly from Shigella [20].

STEC is recognized as an important cause of food-borne disease in humans and causes large outbreaks worldwide [21]. E. coli 0157: $\mathrm{H7}$ is the leading cause of hemorrhagic colitis, hemolytic-uremic syndrome (HUS), and thrombotic thrombocytopenic purpura (TTP) in man. These illnesses may lead to death due to improper absorption of nutrients and destruction of certain tissues in the target organs [22, 23]. People of all ages are susceptible to infection with STEC. However, the young and the elderly are more susceptible and are more likely to develop more serious symptoms [24]. Domestic and wild animals are sources of EHEC 0157:H7 but the major animal carriers are healthy domesticated ruminants, primarily cattle and to a lesser extent, sheep, and possibly goats. Fresh meat and raw milk are, nevertheless, considered as common vehicles for E. coli, particularly for the EHEC (0157:H7) strain. Contamination of meat usually occurs during animal slaughter, as a result of poor slaughter practices, abattoir hygiene, and animal handling practices $[20,25]$.

Foods of bovine origin are frequently implicated in human outbreaks of Shiga toxin-producing Escherichia coli (STEC) 0157 [26, 27]. Shiga-toxigenic E. coli is transmitted by the fecal-oral route by either consumption of contaminated food or water, from direct contact with infected animals, or via person-to-person contact. Moreover, series of studies on the resistance of $E$. coli which were isolated from animals and humans have strongly suggested that those bacteria which are resistant to antimicrobials used in animals would also be resistant to antimicrobials used in humans [28, 29, 30]. In general, antimicrobial resistance is a global public health problem, and growing scientific evidence indicates that it is negatively impacted by both human and animal antimicrobial usages [31]. Although antimicrobial 
therapy is not the primary tool for treating infections caused by STEC 0157:H7, multidrug-resistant (MDR) STEC 0157:H7 is a public health issue as those strains participate in a reservoir of resistance genes that could be easily exchanged between Enterobacteriaceae in the host and the environment [32]. But little is currently known about the molecular basis of multidrug resistance in STEC 0157:H7 isolates of food origin [33]. So, it is of paramount importance to systematically investigate and characterized this recurring food-borne disease. Thus, the current study was conducted to isolate and characterize Shiga toxin-producing E. coli 0157:H7 from raw milk, yogurt, and meat of bovine origin from different sources in the study area and to determine the antimicrobial susceptibility pattern of the isolates.

\section{Materials And Methods}

\section{Study area}

The study was conducted from December 2014 to June 2015 in Mekelle city. Mekelle is the capital city of Tigray Regional State, situated about $783 \mathrm{~km}$ North of Addis Ababa at $38.5^{\circ}$ East longitude and $13.5^{\circ}$ North latitude at an altitude of 2300 above sea level. The city has a total population of 215,546 [34], 308 cafeterias, 292 restaurants, 258 supermarkets, and an active urban-rural exchange of goods which has 30000 micro and small enterprises [35]. The weather condition is hot and dry. The mean annual rainfall of the area is $628.8 \mathrm{~mm}$ and an annual average temperature of $21^{\circ} \mathrm{C}$ [36].

\section{Study design and study population}

A cross-sectional study on Shiga toxin-producing E. coli 0157:H7 was conducted from December 2014 to June 2015 on raw milk, yogurt, and meat samples collected from different sources and parts of Mekelle City, Tigray, Ethiopia. The study populations comprised of purposively selected milking dairy cows and slaughtered cattle found in Mekelle City.

\section{Sampling technique and sample collection}

A total of 284 samples of bovine origin, comprised of raw milk $(n=145)$, yogurt $(n=48)$, and meat $(n=91)$, were collected using a purposive random sampling technique. These samples were collected based on the willingness of the owners until the required sample size was achieved. Raw milk samples were aseptically collected directly from the teats of lactating cows $(n=100)$, whole-sellers $(n=17)$, cafeterias $(n=28)$, and similarly the yogurt samples were collected from dairy farms $(n=26)$ and cafeterias $(n=22)$ using a sterile universal bottle. However, the raw meat samples were collected from abattoirs $(n=55)$, butchery shops $(n=16)$, and restaurants $(n=20)$ during slaughtering and selling. Then, the sections of meat samples were aseptically removed and placed in separate sterile plastic bags to prevent spilling and cross-contamination. Both samples were transported to the Veterinary Microbiology Laboratory of College of Veterinary Sciences, Mekelle University using an icebox and stored at $+4^{\circ} \mathrm{C}$ until the laboratory work was conducted. 


\section{Isolation and identification of E. coli and Shiga toxin- producing E. coli 0157:H7.}

\section{Microbiological procedures}

Isolation of E. coli was attempted according to [37] with slight modification. A part of each sample (10 ml or $10 \mathrm{~g}$ ) was enriched in peptone water (HiMedia, India) $(90 \mathrm{ml})$ and was incubated at $37^{\circ} \mathrm{C}$ for $24 \mathrm{~h}$. Enriched samples were inoculated on MacConkey Agar (MCA) (HiMedia, India) by four flame technique, and plates were incubated at $37^{\circ} \mathrm{C}$ for $24 \mathrm{~h}$. Pink-colored colonies were considered presumptive of $E$. coli. Gram staining was performed as per procedures described by [38] to determine the size, shape, and arrangement of bacteria. The organisms revealed gram-negative, pink-colored with rod-shaped appearance, and arranged in single or in pair were suspected as $E$. coli.

A single well-isolated colony was picked from MCA and streaked on Eosin Methylene Blue Agar (EMB) (HiMedia, India) and incubated at $37^{\circ} \mathrm{C}$ for $24 \mathrm{~h}$. The characteristic green metallic sheen growth of colonies is a presumptive identification for E. coli. Colony morphology and colors on MCA and EMB agar plates together with the Gram stain procedure were used as an initial identification of $E$.

coli colonies [39]. Such colonies were taken from EMB into nutrient broth and agar for further biochemical examination. Standard biochemical tests (Catalase test, Indole, Methyl red, Voges-Proskauer test, Nitrate reduction, Citrate utilization, and Urease production) were used as confirmation of identification [40, 41, $42,43,44,45,46]$. Triple Sugar Iron test was performed according to [47]. Carbohydrate fermentation tests of the isolates were performed according to the method of [43]. Colonies, that were confirmed as E. coli, were further be subcultured onto MacConkey Agar with Sorbitol. A bacterial strain that was used as quality control organisms in this study was a standard strain of E. coli ATCC 25922.

\section{PCR amplification of the pal, eaeA stx1, and sxt2 virulence genes of $E$. coli}

E. coli genomic DNA extraction and purification were performed as per the protocol given by PureLink $\circledast$ Genomic DNA Purification Kit, USA, for Gram-negative organisms, and the total genomic DNA was checked by running on $1.0 \%$ agarose gel.

All the presumptive isolates' DNA were subjected to multiplex PCR for analyzing for the presence of the $p a l[48]$, eae [49], stx1, and stx2 [50] genes, and further modified by [51]. The amplification was done according to the protocol reported by [52] and [53] using the following specific primers: ECPAL-F-5'GGC AAT TGC GGC ATG TTC TTC C3' and ECPAL-R-5'CCG CGT GAC CTT CTA CGG TGA3' for E. coli (280 bp); EHEC-F-5'TGG TAC GGG TAA TGA AAA3' and EHEC-R-5'AAT AGC CTG GTA GTC TTG T3' for eae gene of EHEC (360 bp); Stx1-F-5'ATA AAT CGC CAT TCG TTG ACT AC3' and Stx1-R-5'AGA ACG CCC ACT GAG ATC ATC3' for stx1 (180 bp); and Stx2-F-5'GGC ACT GTC TGA AAC TGC TCC3' and Stx2-R-5'TCG CCA GTT 
ATC TGA CAT TCT G3' for stx2 (255 bp). Each reaction mixture (50 $\mu \mathrm{l})$ consisted of $5 \mu \mathrm{l}$ of $10 x$ reaction buffer $(500 \mathrm{mM} \mathrm{KCl}, 15 \mathrm{mM} \mathrm{MgCl} 2,100 \mathrm{mM}$ Tris HCl pH 8.3, $0.1 \% \mathrm{w} / \mathrm{v}$ gelatin), $5 \mu$ l of template DNA, $1 \mu \mathrm{l}$ of each primer (the primers were used at a final concentration of $100 \mathrm{M}$ ), $3 \mu \mathrm{l}$ of $10 \mathrm{mM}$ dNTP mixture (at a concentration of $100 \mu \mathrm{l}$ each), and $1 \mu \mathrm{l}$ of Taq polymerase (3U/I). The remaining volume of the reaction mixture was nuclease-free water. The amplification was carried using a Tianlong PCR Thermocycler with thermal cycling conditions of an initial denaturation at $94^{\circ} \mathrm{C}$ for $6 \mathrm{~min}$, followed by 35 cycles of denaturation at $94^{\circ} \mathrm{C}$ for $45 \mathrm{~s}$, annealing at $55^{\circ} \mathrm{C}$ for $30 \mathrm{~s}$, extension at $72^{\circ} \mathrm{C}$ for $45 \mathrm{~s}$, and with a final extension at $72^{\circ} \mathrm{C}$ for $6 \mathrm{~min}$. Finally, PCR products were separated in a horizontal equipment system by running on a $1.5 \%(\mathrm{w} / \mathrm{v})$ agarose gel containing $0.5 \mathrm{~g} / \mathrm{ml}$ ethidium bromide for $55 \mathrm{~min}$ at $110 \mathrm{~V}$ using 1XTAE buffer (40 mM Tris, $1 \mathrm{mM}$ EDTA, and $20 \mathrm{mM}$ glacial acetic acid, pH 8.0). The amplicons were visualized under UV-light gel doc and their molecular weight was estimated by comparing them with 100 bp DNA molecular weight marker (Solis BioDyne, Tartu, Estonia) [54].

\section{Antibiotic sensitivity testing}

The isolates of $E$. coli were screened for in vitro antimicrobial susceptibility using the agar disk diffusion method described by [55]. For this, the following seven different antibiotic discs (Oxoid Ltd., Basingstoke, Hampshire, England) with their concentrations given in parentheses were used in the antibiograms:

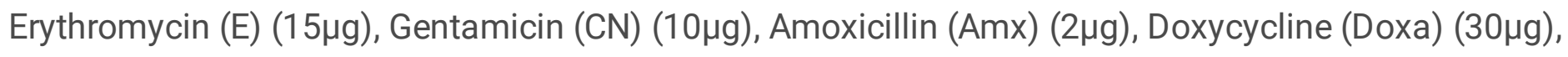
Tetracycline (TE) $(30 \mu \mathrm{g})$, Penicillin (P) $(10 \mu \mathrm{g})$, and Sulfamethoxazole (SXT) $(20 \mu \mathrm{g})$. Four to five wellisolated colonies from nutrient agar plates were transferred into tubes containing $5 \mathrm{ml}$ of a normal saline solution until it achieved the $0.5 \mathrm{McF}$ arland turbidity standards, and then a sterile cotton swab was dipped into the adjusted suspension and then spread evenly over the entire surface of the plate of Mueller-Hinton agar (Oxoid Ltd., Basingstoke, Hampshire, England) to obtain uniform inoculums. The plates were then allowed to dry for 3 to $5 \mathrm{~min}$. Antibiotic impregnated discs were then applied to the surface of the inoculated plates with sterile forceps. After 18 to $24 \mathrm{~h}$ of incubation at $37^{\circ} \mathrm{C}$, the plates were examined and the clear zone (inhibition zones of bacterial growth around the antibiotic disc including the disc) diameter for individual antimicrobial agents was measured using a digital caliper and then translated into Sensitive (S), Intermediate (I), and Resistant (R) categories according to the interpretation table of the Clinical and Laboratory Standard Institute [56].

\section{Data management and analysis}

All collected data were entered into Microsoft Excel Sheet and analyzed through the SPSS Version 16. Accordingly, descriptive statistics such as percentages and frequency distribution were used to determine the prevalence in the food items, and Chi-square $\left(\chi^{2}\right)$ test was applied to assess the association.

\section{Results}




\section{The prevalence of E. coli and Shiga toxin-producing E. coli 0157:H7}

Out of the total 284 samples collected from the different sample sources, 70 (24.64\%) were found to be positive for E. coli. The sample-based prevalences of meat, raw milk, and yogurt samples were 41 (45.05\%), $18(12.41 \%)$, and $11(22.91 \%)$, respectively. There was a significant difference $(p<0.05)$ among the different sample types in the prevalence of $E$. coli (Table 1). Of the total isolated E. coli isolates, $14.29 \%$ were found to be Shiga toxin-producing E. coli 0157:H7.

Table 1

Prevalence of E. coli among the different sample types

\begin{tabular}{|c|c|c|c|c|}
\hline Sample types & No. of examined & No. (\%) of positive samples & $x^{2}$ & $P$-value \\
\hline Meat & 91 & $41(45.05 \%)$ & \multirow[t]{4}{*}{32.1} & \multirow[t]{4}{*}{0.000} \\
\hline Raw milk & 145 & $18(12.41 \%)$ & & \\
\hline Yogurt & 48 & $11(22.91 \%)$ & & \\
\hline Total & 284 & 70 (24.64\%) & & \\
\hline
\end{tabular}

Prevalence rates of $56.25 \%, 40 \%$, and $50 \%$ were recorded in meat samples collected from butchery, abattoir, and restaurant, respectively. The prevalence of E. coli for raw milk samples collected from farms, whole-sellers, and cafeterias were $10 \%, 17.64 \%$, and $17.85 \%$, respectively. Whereas yogurt samples collected from farms and cafeterias were found to be $23.07 \%$ and $22.72 \%$, respectively. The chi-square analysis result revealed that all sample collection sources showed a significant difference $(p<0.05)$ in $E$. coli positivity (Table 2). 
Table 2

Prevalence of $E$. coli among the different sample types and sample sources

\begin{tabular}{|c|c|c|c|c|c|}
\hline $\begin{array}{l}\text { Sample } \\
\text { type }\end{array}$ & $\begin{array}{l}\text { Site of } \\
\text { collection }\end{array}$ & $\begin{array}{l}\text { Total No. of samples } \\
\text { examined }\end{array}$ & $\begin{array}{l}\text { Total No. of samples } \\
\text { positive }\end{array}$ & $\chi^{2}$ & $\begin{array}{l}P \text { - } \\
\text { value }\end{array}$ \\
\hline \multirow[t]{4}{*}{ Meat } & Abattoir & 55 & $22(40 \%)$ & \multirow[t]{4}{*}{35.2} & \multirow[t]{4}{*}{0.000} \\
\hline & Butchery & 16 & 9 (56.25\%) & & \\
\hline & Restaurant & 20 & $10(50 \%)$ & & \\
\hline & Total & 91 & 41 (45.05\%) & & \\
\hline \multirow[t]{4}{*}{ Raw milk } & Farm & 100 & $10(10 \%)$ & \multirow[t]{4}{*}{35.2} & \multirow[t]{4}{*}{0.000} \\
\hline & Whole seller & 17 & $3(17.64 \%)$ & & \\
\hline & Cafeteria & 28 & $5(17.85 \%)$ & & \\
\hline & Total & 145 & $18(12.41 \%)$ & & \\
\hline \multirow[t]{3}{*}{ Yogurt } & Farm & 26 & $6(23.07 \%)$ & \multirow[t]{3}{*}{35.2} & \multirow[t]{3}{*}{0.000} \\
\hline & Cafeteria & 22 & $5(22.72 \%)$ & & \\
\hline & Total & 48 & $11(22.91 \%)$ & & \\
\hline
\end{tabular}

\section{PCR amplification results of the virulence genes of E. coli}

The PCR result indicated that all (100\%) of the tested isolates of E. coli carried the pal gene and $41.67 \%$ eae gene (EHEC). Among the eae gene carried E. coli isolates $40 \%$ were carried $s t x 1$ gene, and $60 \%$ of them were carried stx2 gene.

\section{Antimicrobial susceptibility profile of $\mathrm{E}$. coli isolates}

The $E$. coli isolates isolated from meat, raw milk, and yogurt were showed the highest level of sensitivity for Gentamycin (91.7\%). However, the highest level of resistance was observed against Amoxicillin (95.8\%) (Table 3). Multidrug resistance was detected in $75 \%$ of the isolates. 
Table 3

In vitro antimicrobial drug sensitivity results of $E$. coli isolates

\begin{tabular}{|llll|}
\hline Antimicrobial agents & \multicolumn{2}{l}{ Result } & \\
\cline { 2 - 4 } & Sensitive & Intermediate & Resistant \\
\hline Gentamycin & $22(91.7 \%)$ & $0 \%$ & $2(8.3 \%)$ \\
\hline Penicillin & $1(4.2 \%)$ & $1(4.2 \%)$ & $22(91.7)$ \\
\hline Amoxicillin & $1(4.2 \%)$ & $0 \%$ & $23(95.8 \%)$ \\
\hline Doxycycline & $10(41.7 \%)$ & $2(8.3 \%)$ & $12(50 \%)$ \\
\hline Tetracycline & $14(58.3)$ & $0 \%$ & $10(41.7 \%)$ \\
\hline Sulfamethoxazole & $19(79.2 \%)$ & $0 \%$ & $5(20.8 \%)$ \\
\hline Erythromycin & $7(29.2)$ & $4(16.7 \%)$ & $13(54.2 \%)$ \\
\hline
\end{tabular}

\section{Discussion}

The current study revealed an overall prevalence rate of $24.64 \%$ for E. coli. This finding was in line with the reports of [57] (20\%), [58] (20.2\%), [59] (21.6\%), [60] (23.4\%), [61] (23.7\%), [10] (27.3\%), and [62] (27.3\%). It was higher than the reports of [63] (8.15\%), [64] (9.23\%), [65] (12.38\%), [66] (15.89\%), and [67] (19\%). However, it was lower than the findings of [68] (33.9\%), [69] (38\%), [70] (46.26\%), [71] (61.7\%), and [72] (63\%). The present study also revealed an overall prevalence of $14.29 \%$ for Shiga toxin-producing $E$. coli 0157:H7 (EHEC). This finding was almost in agreement with reports [73] (10.2\%), [61] (10.4\%), [74] (10.4\%), [75] (10.9\%), [76] (11.43\%), [77] (17.47\%), and [71] (18\%). But, it was higher than the findings of [78] (0.54\%), [64] (1.92\%), [79] (2.1\%), [65] (2.4\%), [80] (2.4\%), [68] (2.9\%), [81] (3.38\%), [57] (3.5\%), [82] (4.2\%), [67] (5.2\%), [58] (5.4\%), [83] (6.3\%), [84] (8.8\%), [85] (9\%), [60] (9.1\%), and [86] (9.3\%). However, it was lower than the finding of [87] (25\%), [88] (36.1\%), [89] (41.66\%), and [90] (69\%). The variation might be due to differences in sample types of food of bovine origin, sources of the samples, methodological approaches, diagnostic techniques, prevalence calculation/interpretation, geographical locations, hygienic condition, handling and transportation of samples, and contamination rates from utensils and personnel. Generally in the present findings prevalence of $E$. coli was higher in the samples collected from butchery, restaurant, cafeteria, and whole seller other than the other sources. This might be due to food establishments in the study area were found to have poor sanitation and were not maintained well, specifically, poor repair condition of kitchens, improperly managed toilet facilities, inappropriate solid waste receptacles, lack of standard dishwashing compartments, and lack of handwashing lavatories in a large number of establishments [8].

The antimicrobial susceptibility test results of $E$. coli isolates isolated from meat, raw milk, and yogurt were showed the highest level of sensitivity for Gentamycin (91.7\%). It was almost in agreement with the 
reports of [67] (100\%), [57] (82.5\%), and [91] (81.82\%). The 79.2\% isolates were susceptible to Sulfamethoxazole which was in agreement with the reports of [91] (78.79\%). However, the highest level of resistance was observed against Amoxicillin (95.8\%) which was in line with the reports of [60] (100\%), and [78] (100\%). In addition, $41.7 \%$ of the isolates were resistant to Tetracycline which was in agreement with the reports of [59] (47.6\%) but was higher than the findings of [92] (4\%), [73] (5.1\%), [77] (23.08\%), [60] (27.7\%), and [93] (32\%). However, it was lower than the findings of [81] (80.6\%), [68] (81.8\%), [67] (63.63\%), and [91] (60.61\%). The present study was also revealed that $20.8 \%$ of the isolates were showed resistance against Sulfamethoxazole which lower than the findings of [93] (36\%). In general, in this study, $75 \%$ of the isolates were developed multidrug resistance which was higher than the reports of [59] (46.0\%) and [60] (66.3\%) but was lower than the report of [74] (93.2\%). Antimicrobial resistance may arise either spontaneously by selective pressure or due to antimicrobial misuse by humans or overuse in feeding or treatment of animals by farmers [94].

\section{Conclusion And Recommendations}

The present study revealed a relatively high occurrence of $E$. coli as well as Shiga toxin-producing $E$. coli 0157:H7 in food of bovine origin in Mekelle City and isolates developed a high level of multi-drug resistance to the antimicrobials tested. Hence, foods of bovine origin can serve as a potential vehicle for transmitting E. coli, in particular, Shiga toxin-producing E. coli 0157: $\mathrm{H7}$, and its presence indicates a serious public health hazard and give a warning signal for the possible occurrence of a foodborne outbreak in humans through the consumption of raw or undercooked food items. As a result, both its presence and development of a multi-drug resistance should receive particular attention and is an alert for the concerned bodies. Therefore, a coordinated effort is needed to reduce or eliminate the risk posed by these pathogens at various stages in the food chains and on the appropriate use of antimicrobials both in veterinary and human treatment regimes. Moreover, awareness creation should be made on foodborne disease caused by Shiga toxin-producing E. coli 0157:H7 with due consideration on the safe handling and consumption of food of animal origin and selection and safe use of antimicrobials.

\section{Abbreviations}

DNA-Deoxyribonucleic acid; E. coli 0157-Escherichia coli 0157; E. coli-Escherichia coli; EAECEnteroaggregative E. coli; EHEC-Enterohemorrhagic E. coli; EIEC-Enteroinvasive E. coli; EPEC Enteropathogenic E. coli; ETEC-Enterotoxigenic E. coli; ExPEC-Extraintestinal pathogenic E. coli; HUSHemolytic-uremic syndrome; MDR-Multidrug-resistant; PCR-Polymerase Chain Reaction; STEC-Shiga toxin-producing E. coli; Stx-Shiga toxin; TTP-Thrombotic thrombocytopenic purpura; VT-Verotoxin; VTECVerotoxin-producing E. coli

\section{Declarations}




\section{Ethics approval and consent to participate}

Not applicable.

\section{Consent for publication}

Not applicable.

\section{Availability of data and materials}

The datasets used and/or analyzed during the current study are available from the corresponding author on reasonable request.

\section{Competing interests}

The authors declare that they have no competing interests.

\section{Funding}

This research work was funded by College of Veterinary Sciences, Mekelle University.

\section{Authors' contributions}

MW, GG, YT, and NA participated in conception and proposal development, sample collection, laboratory analysis, supervision, validation, data analysis, and write-up of the original draft and reviewing and editing of the final version of the manuscript. $A K, M A, N A, H T$, and $A B$ were involved in the conception and proposal development, data analysis, validation, and write-up of the original draft and reviewing and editing of the final version of the manuscript. All authors contributed to the final version of the manuscript and approved the submission.

\section{Acknowledgments}

The authors would like to acknowledge the College of Veterinary Sciences, Mekelle University for financial support. We would like to extend our acknowledgment to owners, managers, and workers of the different dairy farms, abattoir, butcher shop, restaurant, milk whole seller, and cafeteria of the study site for their keen interest and cooperation during the collection of the samples, and to the College of Veterinary Sciences Staff members who directly or indirectly helped us during the research period. 


\section{References}

1. FAO/WHO. Joint FAO/WHO food standards programmed FAO/WHO coordinating committee for Africa, seventeenth session, Rabat, Morocco; 2007.

2. Ayalew H, Birhanu A, Asrade, B. Review on food safety system: Ethiopian perspective. Afr J Food Sci. 2013; 7:431-40.

3. Yousuf AH M, Ahmed MK, Yeasmin S, Ahsan N, Rahman MM, Islam MM. Prevalence of microbial load in shrimp, Penaeus Monodon and Prawn, Macrobrachium Rosenbergii from Bangladesh. World J Agricultural Sci. 2008; 4: 852 - 55.

4. Abebe E, Gugsa G, Ahmed M. Review on major food-borne zoonotic bacterial pathogens. J Trop Med. 2020; 2020: 1-19.

5. Sheikh SW, Ali A, Ahsan A, Shakoor S, Shang F, Xue T. Insights into emergence of antibiotic resistance in acid-adapted Enterohaemorrhagic Escherichia coli. Antibiotics. 2021; 10: 522.

6. Molla B, Alemayehu D, Salah W. Sources and distribution of Salmonella serotypes isolated from food animals, slaughterhouse personnel and retail meat products in Ethiopia: 1997-2002. Ethiop J Health Dev. 2003; 17(1): 63-70.

7. Kumie A, Mezene A, Amsalu A, Tizazu A, Bikila B. The sanitary condition of food and drink establishments in Awash-Sebat Kilo Town, Afar Region. Ethiop J Health Dev. 2006; 20(3): 201-3.

8. Zeru K, Kumie A. Sanitary conditions of food establishments in Mekelle Town, Tigray, North Ethiopia. Ethiop J Health Dev. 2007; 21(1): 1-9.

9. Woldemariam T, Asrat D, Zewde G. Prevalence of thermophilic Campylobacter species in carcasses from sheep and goats in an Abattoir in Debre-Zeit area, Ethiopia. Ethiopian J Health Dev. 2009; 23(3): 229-33.

10. Haileselassie M, Taddele H, Adhana K, Kalayou S. Food safety knowledge and practices of abattoir and butchery shops and the microbial profile of meat in Mekelle City, Ethiopia. Asian Pac J Trop Biomed. 2013; 3(5): 407-12.

11. Kaper JB, Nataro JP, Mobley HL. Pathogenic Escherichia coli. Nat Rev Microbiol. 2004; 2: 123-40.

12. DiRita V. Enteric bacteria: secretory diarrhea. In: Engleberg, NC, DiRita V, Dermody TS, ed. Mechanisms of Microbial Disease 4th ed. Baltimore, MD: Lippincott Williams and Wilkins; 2007a. p.190-199.

13. DiRita V. Invasive and tissue-damaging enteric bacterial pathogens: bloody diahhhea and dysentery. In: Engleberg, NC, DiRita V, Dermody TS, ed. Mechanisms of Microbial Disease 4th ed. Baltimore, MD: Lippincott Williams \& Wilkins, 2007b. 200-204.

14. Nataro JP, Kaper JB. Diarrheagenic Escherichia coli. Clin Microbiol Rev. 1998; 11(1): 142-201.

15. O'Brien AD, LaVeck GD, Thompson MR, Formal SB. Production of Shigella dysenteriae Type 1-Like Cytotoxin by Escherichia coli. J Infect Dis. 1982; 146(6): 763-69.

16. Konowalchuk J, Speirs JI, Stavric S. Vero response to a cytotoxin of Escherichia coli. Infect Immun. 1977; 18(3): 775-79. 
17. Levine MM, Xu JG, Kaper JB, Lior H, Prado V, Tall B, et al. A DNA probe to identify enterohemorrhagic Escherichia coli of 0157:H7 and other serotypes that cause hemorrhagic colitis and hemolytic uremic syndrome. J Infect Dis. 1987; 156: 175-82.

18. Constantiniu S. Emerging Shiga cytotoxin-producing E. coli. I. Enterohaemorrhagic E. coli 0157: $\mathrm{H} 7$. Prev Med. 2002; 10: 62-78.

19. Effler $P$, Isaacson $M$, Arntzen $L$, Heenan $R$, Canter $P$, Barrett $T$, et al. Factors contributing to the 50 emergence of E. coli 0157 in Africa. Emerg Infect Dis. 2001; 7: 812-19.

20. Kiranmayi CB, Krishnaiah N, Mallika EN. Escherichia coli 0157:H7 - An emerging pathogen in foods of animal origin. Vet World. 2010; 3(8): 382-89.

21. Schmidt MA. LEEways: tales of EPEC, ATEC and EHEC. Cell Microbiol. 2010; 12(11): 1544-52.

22. Cobbaut K, Houf K, Buvens G, Habib I, De, ZL. Occurrence of non-sorbitol fermenting verocytotoxinlacking Escherichia coli 0157 on cattle farms. Vet Microbiol. 2009; 138: 174-78.

23. Earley B, Leonard N. The characterisation of E. coli 0157:H7 isolates from cattle faeces and feedlot environment using PFGE. Vet Microbiol. 2006; 114: 331-36.

24. FDA. Bad bug book: foodborne pathogenic microorganisms and natural toxins Handbook. 2nd ed. US Food and Drug Administration: Silver Spring; 2012.

25. Rahimi E, Kazemeini HR, Salajegheh M. E. coli 0157:H7/NM prevalence in raw beef, camel, sheep, goat, and water buffalo meat in Fars and Khuzestan Provinces, Iran. Vet Res Forum. 2012; 3: 13-7.

26. Bell BP, Goldoft M, Griffin PM, Davis MA, Gordon D.C., Tarr PI, et al. A multistate outbreak of E. coli 0157:H7-associated bloody diarrhea and hemolytic uremic syndrome from hamburgers. The Washington experience. JAMA. 1994; 272: 1349-53.

27. Dodson K, LeJeune J. E. coli 0157:H7, Campylobacter jejuni, and Salmonella prevalence in cull dairy cows marketed in northeastern Ohio. J Food Prot. 2005; 68: 927-31.

28. VSPA (World Society for the Protection of Animals). Resistant bacteria in people and farm animals around the world. 2006.

29. Miles TD, McLaughlin W, Brown PD. Antimicrobial eesistance of $E$. coli isolates from broiler chickens and humans. BMC Vet Res. 2006; 2:7.

30. Umolu PI, Ohenhen ER, Okwu IG, Ogiehor IS. Multiple antibiotic resistant index and plasmid of E. coli in Beef in Ekpoma. Am J Sci. 2006; 2(3): 1-4.

31. Guardabassi $\mid<\mathrm{bi}>,</ \mathrm{bi}>$ Jensen $L B<\mathrm{bi}>,</ \mathrm{bi}>K$ Kruse $H<\mathrm{bi}>,</ \mathrm{bi}>$ Eds. Guide to antimicrobial use in animals<bi $>$.</bi $>$ Blackwell Publishing $<\mathrm{bi}>:</ \mathrm{bi}>$ Ames, lowa<bi $>;</ \mathrm{bi}>2008<\mathrm{bi}>.</ \mathrm{bi}>$

32. Rolain $\mathrm{JM}<\mathrm{bi}>$. $</ \mathrm{bi}>$ Food and human gut as reservoirs of transferable antibiotic resistance encoding genes<bi $>$. $<$ bi $>$ Front Microbiokbi $>$. $<$ bi $2013<\mathrm{bi}>;</ \mathrm{bi}>4<\mathrm{bi}>:</ \mathrm{bi}>173<\mathrm{bi}>.</ \mathrm{bi}>$

33. Zhao S, White DG, Ge B, Ayers S, Friedman S, English L, et al. Identification and characterization of integron-mediated antibiotic resistance among Shiga toxin-producing Escherichia coli isolates. Appl Environ Microbiol. 2001; 67(4): 1558-64. 
34. Central Statistic Authority CSA Federal Democratic Republic of Ethiopia population census commission. Summary and statistical report of population and housing. 2007.

35. Bryant C. Investment opportunities in Mekelle, Tigray State, Ethiopia. 2011.

36. TRHDA. Tigray Regional Housing and Development Agency. Housing report of 2007/2008. 2008.

37. Quinn PJ, Markey BK, Carter ME., Donnelly WJC, Leonard FC, Maguire D. Veterinary microbiology and microbial disease. 1st ed. Blackwell Science Ltd: UK; 2002.

38. Merchant IA, Packer RA. Veterinary bacteriology and virology. 7th ed. The lowa State University Press, Ames: lowa, USA; 1969.

39. Eaton AD, Clesceri LS, Greenberg AE. Standard methods for the examination of water and waste water. 19th ed. American Public Health Association; Washington, DC; 1995.

40. Jarvis CJ, Kellerman GE, Van Rensburg WJJ, Whitehead CJ. The Bacteriology manual. 2nd ed. 1994.

41. Brenner DJ, Krieg NR, Staley JT, Garrity G. Bergey's manual of systematic bacteriology. 2nd ed. 2005.

42. MacFaddin JF. Biochemical tests for identification of medical bacteria. 3rd ed. Lippincott Williams and Wilkins: Philadelphia; 2000.

43. Cheesbrough M. Medical laboratory manual for tropical countries. Microbiol. 1985; 2: 400-80.

44. Snell EE, Wright LD. A microbiological method for the determination of nicotinic acid. J Biol Chem. 1941; 139: 675-86.

45. Simmons J. Standard methods for the examination of water and wastewater. 11th ed. APHA Inc: New York; 1960.

46. Chakraborty SP, KarMahapatra S, Roy S. Biochemical characters and antibiotic susceptibility of $S$. aureus isolates. Asian Pac J Trop Biomed. 2011; 1(3): 192-96.

47. Vanderzant C, Splittstresser DF. Conpendium of methods for the microbiological examination of foods. 3rd ed. American Public Health Association: Washington DC; 1992.

48. Kuhnert $\mathrm{P}$, Nocolet J, Frey J. Rapid and accurate identification of E. coli K-12 strains. Appl Environ Microbiol. 1995; 61: 4135-39.

49. Ellingson JLE, Kozickkpwski JJ, Anderson JF, Carison SA, Sharma VK. Rapid PCR detection ofenterohaemorrhagic E. coli (EHEC) in bovine foodproducts and feces. Mol Cell Probes. 2005; 19: 213-17.

50. Paton AW, Paton JC. Detection and characterization of Shiga toxigenic $E$. coli by using multiplex PCR assays for $s t x 1$, st $x 2$, eaeA, Enterohemorrhagic E. coli htyA, $r f b O_{111}$, and $r f b O_{157}$. J Clin Microbiol. 1998; 36(2): 598-602.

51. Fitzmaurice J. Molecular diagnostic assay for E. coli 0157:H7. Ph.D. Thesis, Department of Microbiology, National University of Ireland, University College Galway: Ireland; 2003.

52. Parekh TS, Subhash R. Molecular and bacteriologicalexamination of milk from different milk animals with special reference to coliforms. Curr Res Biotech. 2008; 1(2): 56-63.

53. Wang G, Clark CG, Rodgers FG. Detection in E. coliof the genes encoding the major virulence factors, the genes defining the $0157: \mathrm{H} 7$ serotype, and components of the type 2 shiga toxin family by 
multiplex PCR. J Clin Microbiol. 2002; 40: 3613-19.

54. Sambrook J, Fritsch EF, Maniatis T. Molecular cloning: A laboratory manual. 2nd ed. Cold Spring Harbour Laboratory Press; 1989.

55. Bauer AW, Kirby WMM, Sherries JC, Turck M. Antibiotic susceptibility testing by a standard single disc method. Am J Clin Pathol. 1966; 45: 493-96.

56. CLSI. Performance standards for antimicrobial susceptibility testing; twenty-fourth informational supplement. CLSI document M100-S24, Wayne PA; 2014.

57. Bedasa S, Shiferaw D, Abraha A, Moges T. Occurrence and antimicrobial susceptibility profile of Escherichia coli 0157:H7 from food of animal origin in Bishoftu town, Central Ethiopia. Int J Food Contam. 2018; 5: 2.

58. Sebsibe MA, Asfaw ET. Occurrence of multi-drug resistant Escherichia coli and Escherichia coli 0157:H7 in meat and swab samples of various contact surfaces at abattoir and butcher shops in Jimma Town, Southwest District of Ethiopia. Infect Drug Resist. 2020; 13: 3853-62.

59. Messele YE, Abdi RD, Yalew ST, Tegegne DT, Emeru BA, Werid GM. Molecular determination of antimicrobial resistance in Escherichia coli isolated from raw meat in Addis Ababa and Bishoftu, Ethiopia. Ann clin microbiol antimicrob. 2017; $16<\mathrm{bi}>(</ \mathrm{bi}>1<\mathrm{bi}>):</ \mathrm{bi}>55<\mathrm{bi}>$. $</$ bi $>$

60. Tadese ND, Gebremedhi EZ, Moge, F, Borana BM, Marami LM., Sarba EJ. Occurrence and antibiogram of Escherichia coli 0157:H7 in raw beef and hygienic practices in abattoir and retailer shops in Ambo Town, Ethiopia. Vet Med Int. 2021; 2021: 1-12.

61. Abebe M, Hailelule A, Abrha B, Nigus A, Birhanu M, Adane, H, et al. Antibiogram of E. coli strains isolated from food of bovine origin in selected Woredas of Tigray Ethiopia. J Bacteriol Res. 2014; 6(3): 17-22.

62. Haftu R, Taddele H, Gugsa G, Kalayou S. Prevalence, bacterial causes, and antimicrobial susceptibility profile of mastitis isolates from cows in large scale dairy farms of Northern Ethiopia. Trop Anim Health Pro. 2012; 44(7): 1765-71.

63. Kumar R, Prasad A. Detection of E. coli and Staphylococcus in milk and milk products in and around Pantnagar. Vet World. 2010; 3(11): 495-96.

64. Yakubu Y, Shuaibu AB, Ibrahim AM, Hassan UL, Nwachukwu RJ. Risk of Shiga toxigenic Escherichia coli 0157:H7 infection from raw and fermented milk in Sokoto Metropolis, Nigeria. J Patho. 2018; 2018:1-5.

65. Atnafie B, Paulos D, Abera M, Tefer, G., Hailu, D, Kasaye S. Occurrence of Escherichia coli O157:H7 in cattle feces and contamination of carcass and various contact surfaces in abattoir and butcher shops of Hawassa, Ethiopia. BMC Microbiol.2017; 17: 24.

66. Mohammed O, Shimelis D, Admasu P, Feyera T. Prevalence and antimicrobial susceptibility pattern of E. coli isolates from raw meat samples obtained from abattoirs in Dire Dawa City, Eastern Ethiopia. Int J Microbiol Res. 2014; 5(1): 35-9.

67. Ababu A, Endashaw D, Fesseha H. Isolation and antimicrobial susceptibility profile of Escherichia coli 0157:H7 from raw milk of dairy cattle in Holeta District, Central Ethiopia. Int J Microbiol. 2020; 
2020: $1-8$.

68. Disassa N, Sibhat B, Mengistu S, Muktar Y, Belina D. Prevalence and antimicrobial susceptibility pattern of E. coli 0157:H7 isolated from traditionally marketed raw cow milk in and around Asosa Town, Western Ethiopia. Vet. Med. Int. 2017; 2017: 1-7.

69. Thaker HC, Brahmbhatt MN, Nayak JB. Study on occurrence and antibiogram pattern of Escherichia coli from raw milk samples in Anand, Gujarat, India. Vet World. 2012; 5(9):556-59.

70. Negesse W, Fufa A, Bihonegn W. Isolation, identification and antimicrobial susceptibility profiles of $E$. coli 0157:H7 from raw cow milk in and around Modjo Town, Ethiopia. J A Sci. 2020; 16(6):62-9.

71. Balcha E, Kumar A, Tassew H. Evaluation of safety of beef sold in and around Mekelle with special reference to Enterohemorrhagic Escherichia coli 0157:H7. Glob Vet. 2014;12(4): 569-72.

72. Ali AA, Abdelgadir WS. Incidence of Escherichia coli in raw cow's milk in Khartoum State. British J Dairy Sci. 2011; 2(1): 23-6.

73. Bekele T, Zewde G, Tefera G, Feleke A, Zerom K. Escherichia coli 0157:H7 in raw meat in Addis Ababa, Ethiopia: Prevalence at an abattoir and retailers and antimicrobial susceptibility. Int. J. Food Contam. 2014;1:4.

74. Mekuria A, Beyene T. Zoonotic bacterial pathogens isolated from food of bovine in selected Woredas of Tigray, Ethiopia. World Appl Sci J. 2014; 31(11): 1864-68.

75. Akomoneh EA, Esemu SN, Kfusi JA, Ndip RN, Ndip LM. Prevalence and virulence gene profiles of Escherichia coli 0157 from cattle slaughtered in Buea, Cameroon. PLoS One. 2020; 15(12): e0235583.

76. Beyi AF, Fite AT, Tora E, Tafese A, Genu T, Kaba T, et al. Prevalence and antimicrobial susceptibility of Escherichia coli 0157 in beef at butcher shops and restaurants in central Ethiopia. BMC Microbiol. 2017; 17(1): 49.

77. Mohammadi P, Abiri R, Rezaei M, Salmanzadeh-Ahrabi S. Isolation of Shiga toxin-producing Escherichia coli from raw milk in Kermanshah, Iran. Iran J Microbiol. 2013; 5(3): 233-38.

78. Abdissa R, Haile W, Fite AT, Beyi AF, Agga GE, Edao BM, et al. Prevalence of Escherichia coli 0157:H7 in beef cattle at slaughter and beef carcasses at retail shops in Ethiopia. BMC Infect Dis. 2017; 17(1): 277.

79. Geresu MA, Regassa S. Escherichia coli 0157:H7 from food of animal origin in Arsi: Occurrence at catering establishments and antimicrobial susceptibility profile. Sci World J. 2021; 2021:1-10.

80. Carney E, O’Brien SB, Sheridan JJ, McDowell DA, Blair IS, Duffy G. Prevalence and level of Escherichia coli 0157 on beef trimmings, carcasses and boned head meat at a beef slaughter plant. Food Microbiol. 2006; 23(1): 52-9.

81. Ahmed AM, Shimamoto T. Molecular analysis of multidrug resistance in Shiga toxin-producing Escherichia coli 0157:H7 isolated from meat and dairy products. Int J Food Microbiol. 2015; 193 : 6873. 
82. Hiko A, Asrat D, Zewde G. Occurrence of Escherichia coli 0157:H7 in retail raw meat products in Ethiopia. J Infect Dev Ctries. 2008; 2(5): 389-93.

83. Gutema $F D<\mathrm{bi}>,</ \mathrm{bi}>$ Rasschaert $G<\mathrm{bi}>,</ \mathrm{bi}>A g g<\mathrm{bi}>,</ \mathrm{bi}>G E<\mathrm{bi}>,</ \mathrm{bi}>$ Jufare $A<\mathrm{bi}>,</ \mathrm{bi}>$ Duguma $A B<\mathrm{bi}>,</ \mathrm{bi}>A b d i R D<\mathrm{bi}>,</ \mathrm{bi}>$ et al. Occurrence, molecular characteristics, and antimicrobial resistance of Escherichia coli 0157 in cattle, beef, and humans in Bishoftu Town, Central Ethiopia<bi>.</bi> Foodborne Pathog Dis.<bi>.</bi> 2021<bi $>$;</bi $>18<b i>(</ b i>1<b i>):$ doi:</bi> 10

.1089/fpd.2020.2830<bi>.</bi>

84. Vanitha HD, Sethulekshmi C, Latha C. An epidemiological investigation on occurrence of enterohemorrhagic Escherichia coli in raw milk. Vet World. 2018; 11(8): 1164-70.

85. Dutta S, Deb A, Chattopadhyay UK, Tsukamoto T. Isolation of Shiga toxin-producing Escherichia coli including 0157:H7 strains from dairy cattle and beef samples marketed in Calcutta, India. J Med Microbiol. 2000; 49:765-67

86. Haile $A F<\mathrm{bi}>,</ \mathrm{bi}>$ Kebede $D<\mathrm{bi}>,</ \mathrm{bi}>$ Wubshe $A K<\mathrm{bi}>$. $</ \mathrm{bi}>$ Prevalence and antibiogram of Escherichia coli 0157 isolated from bovine in Jimma, Ethiopia: Abattoir based survey<bi>.</bi> Ethiop Vet J. 2017<bi>;</bi> 21(2): 109-20.

87. Garbaj, AM., Awad EM, Azwai SM, Abolghait SK, Naas HT, Moawad AA, et al. Enterohemorrhagic Escherichia coli 0157 in milk and dairy productsfrom Libya: Isolation and molecular identification by partial sequencing of 16S rDNA. Vet World. 2016; 9(11): 1184-89.

88. Llorente P, Barnech L, Irino K, Rumi MV, Bentancor A. Characterization of Shiga toxin-producing Escherichia coli isolated from ground beef collected in different socioeconomic strata markets in Buenos Aires, Argentina. Biomed Res Int. 2014; 2014:1-9.

89. Nehoya KN, Hamatui N, Shilangale RP, Onywera H, Kennedy J, Mwapagha LM. Characterization of Shiga toxin-producing Escherichia coli in raw beef from informal and commercial abattoirs. PLoS One.2020; 15(12): e0243828.

90. Islam MA, Mondol AS, Azmi IJ, de Boer E, Beumer RR, Zwietering MH, et al. Occurrence and characterization of Shiga toxin-producing Escherichia coli in raw meat, raw milk, and street vended juices in Bangladesh. Foodborne Pathog Dis. 2010; 7(11): 1381-85.

91. Hailu S. Isolation, identification and antibiotic susceptibility of $E$. coli from diarrheic calves in and around Holeta Town, Central Ethiopia. J. Vet. Med. Res. 2020; 7(5): 1197.

92. Carvalho D, Kunert-Filho HC, Simoni C, de Moraes LB, Furian TQ, Borges KA, et al. Antimicrobial susceptibility and detection of virulence-associated genes of Escherichia coli and Salmonella spp. isolated from domestic pigeons (Columba livia) in Brazil. Folia Microbiol. 2020; 65: 735-45.

93. Mora A, Blanco JE, Blanco M, Alonso MP, Dhabi G, Echeita A, et al. Antimicrobial resistance of Shiga toxin (verotoxin)-producing Escherichia coli 0157:H7 and non-0157 strains isolated from humans, cattle, sheep and food in Spain. Res J Microbiol. 2005; 156(7): 793-806.

94. Schroeder CM, Zhao C, DebRoy C, Torcolini J, Zhao S, White DG, et al. Antimicrobial resistance of Escherichia Coli 0157 isolated from humans, cattle, swine, and food. Appl Environ Microbiol. 2002; 
68: 576-81.

Page 18/18 